\title{
BREVE REFLEXÃO SOBRE OS ASPECTOS FILOSÓFICOS DA EXPERIÊNCIA COM O GENOMA HUMANO
}

\author{
David Teixeira de Azevedo \\ Professor Doutor do Departamento de Direito Penal da \\ Faculdade de Direito da Universidade de São Paulo
}

Resumo

Os paradoxos de uma avassaladora tecnologia, investigações que permitem extraordinários avanços, as valiosas conquistas da Engenharia Genética e da clonagem e o universo de possibilidades aberto aos caminhos do homem são os pontos abordados pelo autor, com belissimas conclusões.

Abstract

The overpowering technology's paradoxes, inquires that allow extraordinaries advances, valuables acquires of the Genetics Engineer and cloning and the universe of possibilities openned to the human ways are the points boarded by the author, with wonderful conclusions.

Unitermos: genoma humano; clonagem; Engenharia Genética; investigação científica; vida humana.

"Como é bela a Humanidade! Oh! Admirável mundo novo em que vivem tais pessoas!"

(Shakespeare, A tempestade)

I. Introdução.

No filme The $6^{\text {th }}$ Day, dirigido por Roger Spottiswood e estrelado por Arnold Schwarzenegger, que trata do tema da clonagem de seres vivos, há uma empresa especializada em clonagem humana, sendo médico responsável o Dr. Weir. Katherine, a esposa deste último, que já fora clonada mas adoecera gravemente outra vez, afirma: "Eu quero morrer. Meu tempo já passou" Em discussão com o proprietário da empresa, diz o Dr. Weir: "Eu amo minha mulher muito, tanto que prometi não a trazer de volta"

Essa fita ilustra muito bem a perplexidade e ambigüidade trazidas pela avalanche tecnológica bem característica deste tempo. A passagem transcrita emoldura, exemplarmente, a angústia e a contradição de sentimentos surgidos da experiência humana, trágica, de fazer possível a vida sem limite temporal. 
II. Avassaladora tecnologia: um paradoxo.

As investigações levadas adiante pelos físicos e o desvendar dos segredos dos átomos despertaram os bioquímicos para pesquisa dos seres vivos. Nesse campo despontou a Genética, cujo foco é a matéria viva e sua reprodução. Investigando-se a fantástica e intrincada intimidade de funcionamento das moléculas, identificaram-se os ácidos nucléicos, base da herança do ser vivo. Com Miescher isolando a nucleína, denominada ácido nucleico, e, verificando-se ser esta a base da herança dos caracteres dos seres vivos, Macarty Aver e Macleod "determinaram que um dos ácidos nucléicos, o ADN ou ácido desoxirribonucléico, podia transferir uma caracteristica ausente antes da transmissão". Daí, como já se observou, foi um passo para Watson e Crick proporem, em 1954, a estrutura helicoidal, dupla, como forma de explicação da rearrumação dos átomos na molécula de ADN.

Marcante é que "essas e outras investigações permitiram avanços extraordinários no campo genético, com a descoberta mesma da estrutura da vida, com ganhos incontáveis para a denominada engenharia genética com a tecnologia do DNA recombinante, de modo a fazer a multiplicação de genes dos mais variados organismos, havendo possibilidade de modificação do genoma, ou seja, da base hereditária de uma célula viva, tornando possivel a geração de novos seres, denominados "organismos geneticamente modificados" Exemplo dessa tecnologia é a criação de organismos transgênicos, que esteve tão em moda quando do movimento contra os grãos de soja importados pelo Brasil, ou também o rato gigante em que foi introduzido gene humano responsável pelo crescimento.

Há valiosas conquistas da Engenharia Genética como o melhoramento genético, a terapia genética, com a retirada de genes defeituosos a fim de serem reparados e reinjetados no organismo, além da detecção de doenças antes mesmo do nascimento do ser, a possibilitar uma espécie de limpeza e conserto genético. Muitas doenças hereditárias, entre três a quatro mil, poderão ser mapeadas e assim erradicadas ${ }^{2}$ Como acrescenta a redação do site Terra, "novos produtos poderão se beneficiar das descobertas. Empresas norte-americanas de biotecnologia estão conduzindo experiências de evolução acelerada para criar uma geração desde superdetergentes a remédios ultrapotentes. Na chamada evolução dirigida, os biotecnólogos pressionam os genes a experimentar mutações, obtendo em dias ou semanas o que demoraria anos na natureza. Por exemplo: determinadas bactérias levam décadas para evoluir e se tornar resistentes aos antibióticos. Os laboratórios, porém, podem criar em poucos dias supergermes para testar os novos antibióticos"

A Engenharia Genética permitiu igualmente a clonagem, tão em voga quando da ovelha Dolly, em que foi realizada a cópia idêntica de outro ser vivo,

1. A cxposição scguiu a linha de Cclso Pachcco Fiorillo c Marcclo Abclha Rodrigucs, Dircito ambiental e patrimônio genético, Bclo Horizontc, Editora Dcl Rcy, 1996, pp. 151 c ss.

2. Fonte: AFP/Terra. 
produzido artificial e assexuadamente, tornando possível a realização da clonagem de embriões humanos, trabalho desenvolvido pela Advanced Cell Technology, uma pequena empresa de biotecnologia de Worcester, próximo a Boston, Massachusetts. Segundo alegam, a finalidade da pesquisa com os embriões não seria a reprodução, mas simplesmente constituir fonte de "células-tronco", em tese capazes de se transformar em tecido e órgãos humanos. Todos os embriões clonados, todavia, morreram.

Há acesa disputa entre os dois organismos responsáveis pela pešquisa da decodificação genética, a empresa Celera Genomics, grupo privado, e o Human Research Project, empreendimento que conta com a colaboração de cientistas do mundo inteiro. De qualquer modo, Eric Lander, um dos principais pesquisadores do projeto público, afirmou que os cientistas não poderão criar as terapias sem a ajuda de "empresas dispostas a investir capital", o que sugere intensos interesses econômicos, em especial na área de fármacos.

A esse respeito, a Autogen Ltda., empresa australiana no campo de investigação genética, adquiriu do Governo tonganês, minúsculo arquipélago de 108 mil habitantes no Pacífico Sul, direitos com exclusividade sobre a diversidade genética da população, de modo a criar um banco de dados a partir do DNA dos habitantes, em troca de royalties consistentes em medicamentos. ${ }^{3}$

No Brasil, as atividades de pesquisas genéticas já permitiram, por intermédio do Projeto Transcriptoma, não apenas o seqüenciamento dos genes mas sua identificação e nomeação, possibilitando o uso útil das informações genéticas. $O$ Projeto Xylella Fastidiosa desenvolvido pela FAPESP tornou possível, num trabalho integral e em tempo recorde, o seqüenciamento dos genes e sua identificação, fazendo factível, por exemplo, o combate e extermínio do amarelinho, doença da citricultura. O benefício econômico para a produção de laranja, uva e outras culturas suscetíveis a esta última bactéria será não apenas dos produtores mas também do órgão de pesquisa, desde que possível o depósito de uma "patente forte", referente aos genes seqüenciados e identificados, com compreensão de suas funções biológicas. O Brasil também se destaca nesse campo com a decodificação do gene responsável pelo câncer de mama. O trabalho foi desenvolvido pelo Projeto Genoma Humano do Câncer, que elevou o País ao posto de segundo fornecedor de informações sobre a doença, por intermédio da tecnologia denominada "Orestes" que permite a leitura do miolo do gene, onde se localizam as informações genéticas mais importantes.

Todo esse quadro é de causar perplexidade. Mostra que se vive num tempo de avassalador progresso científico e tecnológico. Podemos afirmar nunca antes a Humanidade, em tão curto espaço de século, ter avançado conquistas capazes de pôr em xeque a própria natureza do homem, sua posição no mundo e os valores que lhe norteiam e empolgam a existência.

Por contraditório que seja, ao permitir a quebra de modelos ou paradigmas e ao pretender redefinir o papel da ciência (já agora não de caráter universalista e

3. Folla de S. Paulo (Folha Ciência), cdiçào de 23 de novembro, p. A 17. 
"objetivista", herança do Iluminismo, mas sim com um viés construcionista e de plurais visões do mundo natural e axiológico, característico da era Pós-Moderna), o avanço tecnológico e científico marcou o fim da ciência baseada em conhecimento universal e necessariamente verdadeiro, portanto, ciência de paradigmas seguros ${ }^{4}$ Como assinala Lyotard, lembrado por Stanley Grenz" "o apelo à ciência como categoria organizadora e unificadora está enfraquecendo. Especificamente, a noção de uma empresa cientifica única, subdividida em disciplinas paralelas bem definidas, está sendo substituida pela noção de um agregado de áreas de questionamento mal definidas e em constante mutação. Cada uma dessas especialidades ostenta seu próprio "jogo de linguagem" (método ou procedimento de pesquisa) e conduz seu trabalho sen recorrer a uma "metalinguagem cientifica universal que una as ciências e proporcione um arsenal de recursos bem como um conjunto de princípios metodológicos confiáveis" "

E desse esfacelamento ou pulverização da ciência resultou a perda do preciso objetivo da pesquisa. À ciência já não importa a verdade científica mas sim "o grau de desempenho", deixando de lado a indagação científica básica "Será verdade?" para ingresso da pergunta "Para que serve?", valendo antes a utilidade e eficiência da descoberta ainda que não conhecida plenamente a verdade sobre as leis intrínsecas do fenômeno?

A esse repensar da própria atividade da ciência e à mudança de seus paradigmas segue a quebra de valores, que justamente no âmbito tecnológico já têm precária luminosidade. Opera-se uma perigosa relativização moral. Hemingway, espelhando essa relativização, já afirmava no trabalho Morte na tarde: "I know only that what is moral is what you feel good after, and what is immoral is what you feel bad after", e Joseph Jubert em seus Cadernos acrescentava haver pessoas "que só guardam a moral em peça. É um pano de que nunca mandam fazer roupas" Ou seja, há homens que não operam no campo moral e ético na perspectiva de valores imutáveis e transcendentes; não vestem sua existência com a roupagem valorativa, mas se valem de uma ética pragmática, de instante e utilitarista.

$\mathrm{O}$ fato é que se vive um tempo de verdadeira analgesia moral, expressão de um vazio existencial, estando o homem sem valores como norte, perdido do sentido do ser, apenas voltado para o ter e conquistar, numa verdadeira confusão axiológica. Os valores já não brilham de modo a prestar-se a guia seguro para a tomada de decisões eticamente orientadas a respeito de questões as mais delicadas para a própria existência

4. Pós modernismo - Um guia para entender a filossofia de nosso tempo, Sào Paulo, Editora Vida Nova, 1997, p. 78.

5. É proveitosa a consulta à obra de Lyotard, The post-modern condition: a report on knowledge, Minnesota, University of Minnesota, 1984.

6. Op. Cit., pp. 79-80.

7. Cf. op. ct loc. Cit.

8. Intercssante que Hemingway suicidou-se aos 61 anos, após acometido de crises de depressão $c$ choques clétricos, destino semelhante ao de seu fillho, como assinala Marcclo Rubcns Paiva cm artigo inserido na Folha de S. Paulo, Inćditos, Caderno Especial, cdição de 6/10/2001. 
do gênero humano. E nesse terreno de instabilidade ética vai posicionar-se a questão relativa à investigação genética, campo ainda sem fronteiras definidas e cujas formidáveis aquisições científicas são absolutamente perturbadoras.

Algumas questões pungentes despontam nesse cenário, a começar pela possibilidade de uma eugenia genética; que por certo e em larga medida teria agradado o movimento nacional-socialista alemão. Pense-se também na possível criação de superespécies, capazes de causar dano ao meio ambiente, pelo perigoso desequilíbrio ecológico e pelo risco à variabilidade das espécies. Ou, também, no domínio dos interesses econômicos, o aproveitamento da propriedade das patentes de natureza genética, o que daria domínio sobre a vida animal e vegetal a segmentos comprometidos apenas com o lucro financeiro. Outro problema diz respeito ao prolongamento indefinido da vida e a capacidade do planeta de suportar uma superpopulação, para não falar do risco de, com as pesquisas genéticas, buscar-se a correção genética que torne o gene resistente à agressão externa decorrente da interação do homem com o meio degenerado ou com o agente agressor, em prejuizo da verdadeira correção do problema, que está no meio, correção real consistente na recuperação e preservação do meio ambiente como ecossistema equilibrado e sadio, ou, ainda, no tratamento da fonte como origem mesma da patologia do ser humano.

Outras indagações relevantes, como o sigilo dos dados relativos à informação genética, para fins de seguro, escola, casamento, trabalho etc., a problemática que envolve a propriedade intelectual, a criação do Banco de Dados Genéticos, a necessidade de consentimento de mapeamento genético $0^{9} \mathrm{e}$ intrincado ponto do tratamento genético próprio ou de terceiro, a criação de cópia de seres humanos em formas descerebradas como uma espécie de "estepe" biológico para futuros transplantes sem rejeição e, ainda, o direito à informação genética, essas indagações relevantes - repita-se - trazem sutis, elegantes e perigosos temas éticos, que hão de ser resolvidos juridicamente após a decantação dos valores que orientam a própria vida e existência humana.

$O$ fato é que essas perturbadoras conquistas abalam o alicerce e a estrutura dos valores que são fundantes da sociedade moderna e que constituem medula do próprio homem, membro da comunhão social.

III. A vida humana e sua dimensão ética.

O homem vive imerso nos valores, debaixo de uma verdadeira constelação axiológica que lhe orienta a vida, escalona prioridades, define ações e

9. Veja a advertência da redação do Site Terra: "O mapeamento genético também está alertando para outra questão: a da discriminação genética. Instituições e pesquisadores já indlagam se o conhecimento do material genético de uma pessoa não permitirá a sua exclusão social ou econômica. As empresas seguradoras de saidle poderiam, por exemplo, utilizar o mapeamento genético para alterar os valores dos serviços ou excluir clientes que demonstrassem grande propensão a determinadas doenças. Uma pesquisa feita nos EUA pela Time/CNN mostrou que 75\% dos entrevistados não querem que suas companhias de seguro de saúde conheçam seu código genético, por temerem discriminą̧ão. Os pesquisadores jả falam na necessidade de proibir, legalmente, a discriminação genética. 
propõe e fixa objetivos da existência. O homem vive, respira valores. Mesmo quando nega os valores, o homem os afirma, pois decidir envolve sempre um decidir valorativo e eticamente orientado.

O homem não se caracteriza como tal apenas porque dotado de inteligência, capacitado para a elaboração de idéias e juizos, capaz de abstração conceitual e formulação de raciocínio. A bem ver, estar sob o domínio do instinto ou viver orientado tão-apenas pelà inteligência, em essência não faz muita diferença para a existência particular do homem senão enquanto espécie, porque um e outro, instinto e inteligência, são acrômicos, neutros, pragmáticos. Por isso mesmo, a inerência do comportamento humano não reside propriamente no agir inteligente, mas no agir segundo uma escala de valores. Comportamento humano só é humano se debaixo de um determinado universo axiológico, porquanto instinto e inteligência tão-só habilitam o homem à satisfação das necessidades de sobrevivência de acordo com a luta biológica de preservação. A segunda (inteligência) vai distinguir-se do primeiro (instinto) apenas em que há crescente sofisticação no atendimento a essas necessidades, buscando os melhores e mais abreviados meios para cumprimento do maior espectro possível de necessidades e, por extensão, buscando a satisfação de desejos complexos nos seres humanos e elementares e básicos nos demais animais.

O indisputável é que, se não orientado no sentido de realização de valores, situado debaixo de uma constelação axiológica, o homem perde sua própria identidade, bestializa-se, perde de foco sua finalidade de ser humano, em dano à sua dignidade intrínseca.

Os valores, insista-se, é que dão o sentido à vida, pondo resposta à pergunta em como ser verdadeiramente homem e como pode e deve ele cumprir sua missão no mundo. O sentido da vida, portanto, é a medida precisa em que pode cumprir e cumpre o homem um valor ${ }^{10}$. Acentua Johannes Hessen ser o mais alto fim da vida humana justamente a humanização do homem, pelo abrir-se aos valores."

De fato, o fim da vida é a humanização do homem pela porta dos valores, havendo uma inclinação em todas as atividades humanas em direção ao valioso ou desvalioso. Há tensão constante e perene entre a ciência e a técnica, de um lado, e a humanização do homem, de outro. A técnica tende a afirmar-se isenta a valor. Na busca da conquista científica, o trabalho do técnico é de identificação da ordem intrínseca dos fenômenos e da lei que rege e mantém essa ordem, aparentemente sem qualquer preocupação ou contraponto ao universo axiológico. O homem segue sua vocação de tornar-se pedra angular da criação, tarefa somente possível pelo humanizar-se, que nada mais é senão o ser e agir de acordo com os valores supremos da verdade e da bondade.

10. Johannes Hessen, Filosofia dos valores, Coimbra, Arménio Amado, $5^{\text {a }}$ ediçāo, trad. Cabral de Moncada, p. 241.

11. Op. cit., p. 243. 
IV. As pesquisas científicas e seu equacionamento ético.

As coisas se bem vistas, contudo, não se passam bem assim, pois o decidir humano quanto ao objetivo da pesquisa científica já envolve uma opção ou escollha valorativa. O homem, como se afirmou, está imerso nos valores, não podendo nenhuma ação ou obra sua ser compreendida sem a inserção no universo do valioso. A cultura humana, e nela se incluem as conquistas cientificas e tecnológicas, não constitui outra coisa senão a magnetização dos valores no plano do relacionamento e desenvolvimento humano e social.

O objeto da investigação científica, por conseguinte, não pode despregarse do objetivo determinante da investigação mesma, que acaba por condicionar o método ou a técnica de investigação. Isto é, não há objeto de pesquisa sem um preciso objetivo de investigação, ambos com o dever de equacionar a validade, adequação e proporcionalidade do método de investigação. E no objetivo determinante da pesquisa reside uma opção valorativa.

Assim é que não se pode pretender, por exemplo, a cura da aids simplesmente porque se almeja a criação, promoção ou expansão de uma segura sociedade de homossexuais, ou ainda para tornar menos danoso, por exemplo, o estupro. Muito menos se buscará tal cura utilizando-se de método investigativo que implique a inoculação do vírus em pessoas homossexuais ou potenciais vítima do delito de estupro, pessoas absolutamente sadias, causando-lhes debilidade fisica, sofrimento e dor, a fim de constatar eventual eficiência de determinado princípio ativo de droga, ou mesmo para testar o potencial inocuizante de determinada vacina. Não. A pesquisa científica há de estar eticamente endereçada. Essa a razão pela qual existem os Conselhos de Ética de Pesquisa, de que é exemplo o Conselho de Ética da Faculdade de Farmácia da Universidade de São Paulo.

Por isso, num aspecto, e só nesse aspecto, parece correto o materialismo histórico de Marx ou o vitalismo ou biologismo de Spengler, quando afirmam não poder separar-se, como realidades não-permeáveis, o mundo da natureza e o mundo da cultura, como afirmava a escola neokantista alemã de Windelband e Rickert $^{12}$

Aliás, na linha do empirismo, a medida da natureza é a medida do próprio homem, dado que a natureza constitui realidade para o ser cognoscente apenas no que pode ser percebida e conhecida. Esse princípio do homo mensura, proposto por Protágoras, vale não apenas no campo gnoseológico, mas também no axiológico: a natureza existe e vale na exata proporção em que o homem pode conhecê-la e sobre ela proferir seus juízos de valor. Por isso, a natureza faz-se cultura não pelo fortuito agir do homem sobre a matéria, mas pelo agir teleológica e, assim, axiologicamente orientado. O cogito ergo sum cartesiano pode nesse sentido ser substituído pelo judico ergo sum, que enfatiza o sujeito que valora.

12. Rickert, por excmplo, afirmava scr a ciência da naturcza iscnta ou alhcia a valores: ciência da natureza isenta ou alhcia a valores (wertfiei) e da história ou cultura uma realidade referida a valores (wertbeziehend). Cf. Die Grenzen der naturwissenschafilichen Begrifjsbildung c Kulturwissenschaft und Naturwissenschaft, apud Johanncs Hessen, op. cit., p. 250. 
Aliás, o contato entre natureza e cultura já podia ser identificado desde os estóicos, segundo quem a lei da natureza tanto preside a regularidade e a ordem do mundo quanto constitui igualmente regra de comportamento, regra "que a ordem do mundo exige que seja respeitada por [todos] os seres vivos" confiada aos instintos nos animais e à razão no homem ${ }^{13}$

Mesmo nos domínios exclusivos da natureza parece haver um acento valorativo. Por exemplo, na perpetuidade da espécie, como que há uma seleção das funções mais úteis e mais importantes para o progresso e manutenção do equilíbrio natural, de modo a promover a vida, valor matricial. $\mathrm{E}$ também nesse sentido, homem e natureza integram-se e se fundem como ator principal desse movimento universal de preservação da ordem natural do planeta, desde que a vida humana, pelo que creio, é contigua temporalmente à criação do universo, de tal modo que pode afirmar-se existir o universo para o homem e este depender da existência daquele. Assim, o universo físico e biológico de um lado e o homem e os valores de outro constituem grandezas que participam de uma unidade de sentido, irredutiveis todavia em seus atributos, mas interdependentes e complementares.

Com propriedade, Cabral de Moncada afirma serem "os valores a própria vida do homem enquanto homem"'14 e por meio de sua efetivação é que o homem se liga ao mais real de sua existência, na dialética e interpenetração entre o ideal e o real, na história individual e social: ${ }^{15} \mathrm{E}$ nesse terreno do valioso, a experiência do valor é comum dos homens e universal à raça humana, desde que os valores são objetivos e transindividuais, o que, na fórmula existencial de Heidegger, permaneceu na afirmação de caracterizar-se o homem como um "ser com"16 (sein ist mitsein). E nessa incoercivel comunicação e sociabilidade, as consciências se interpenetram, convivem, colaboram na constituição do ser espiritual que é a Humanidade ao largo da história. Como assevera Cabral de Moncada, a vivência do valioso, não-só no que tem de categoria formal, mas em muitos dos seus conteúdos materiais, não é apenas da pessoa mesma, de sorte que não tem somente o palco da consciência espiritual da pessoa no aqui e agora, mas também a dos outros, de muitos outros, freqüentemente a dos homens de toda uma geração, de uma época, de uma civilização e cultura, e talvez até mesmo da Humanidade $^{17}$

O fato é que o homem submerso nos valores busca, consciente ou inconscientemente, o valor absoluto, que será visto no Deus pessoal e criador do mundo 671.

13. Nicola Abbagnano, Verbete "natureza", Dicionário de Filosofia, São Paulo, Ed. Mestre Jou, , p.

14. Filosofia do direito e do estado, Coimbra, cd., v. 2, p. 286.

15. Op. cit., et loc. Cits.

16. Sobre o existencialismo de Heidegger, ver Johannes Hirschberger, História da filosofia, São Paulo, Editora Herder, 1968, pp. 209 c ss.

17. Op. ct loc. Cits. 
dos cristãos; no espírito absoluto do neohegelianismo, de essência racional, um logos laico a palpitar no interior de toda evolução, tanto da vida natural quanto da vida social e da História; no próprio desespero e na absurdidade da vida humana do existencialismo, ou particularmente no nenhum sentido da vida de Sartre, segundo quem o homem "é o ser que projeta ser Deus" "18, mas este está falido, homem cujo projeto resolve-se portanto em fracasso; ou na "nua existência" de Heidegger ou na Transcendência de Jaspers"

Na verdade, a busca do absoluto é a busca de Deus. E a busca de Deus é a busca pelo homem da razão de sua própria vida e o sentido último de sua existência. E havendo sido feito o homem à imagem e semelhança de Deus, na ânsia insuperável de encontrá-lo busca, a meu sentir inutilmente, o absoluto em sua própria existência espiritual (alma), que é eterna. E nesse ser assim espiritualizado e voltado à Transcendência, acha-se o ponto essencial de seu ser, que é a própria dignidade humana.

De tal arte que a pessoa humana é o valor matricial, é o valor-fonte, no qual há concreção e prospecção do valioso. E por ser valor-fonte, valor-primeiro, ele se põe como razão de ser do Estado, seu modelador e ponto referencial. Deve-se por isso dar-lhe incondicional respeito e proteção, desde que se põe como centro de atração e projeção dos valores, exercendo uma força centrípeta e centrífuga de todas as outras expressões axiológicas. ${ }^{20}$

A problemática vai centrar-se, no fundo e ao cabo, na adoção ou rejeição de uma ética pragmática que instrumentaliza a pessoa humana, pondo em segundo plano sua dignidade intrínseca, tendo o homem como um bem relativo. É uma via aberta, como assinala Laura Pallazani, a uma "ética della disponibilità della vita humana", no curso da qual o homem não possui valor em si mesmo, sendo portanto irrelevantes para a Moral e para o Direito as vertentes axiológicas da conduta mesma, nada havendo a orientar e a tolher a liberdade de ação do ser humano."2

\section{A biotecnologia e os valores do homem.}

Toda ação humana é orientada valorativamente. Agir é agir eticamente orientado. E esse prisma ético é colhido pelas ciências de natureza cultural, que buscam em sua investigação não as relações entre os fenômenos, mas o sentido das condutas e

18. Dicionário cit., verbetc "cxistcncialismo", p. 656, Être et néant, p. 656.

19. Ver Régis Jolivet, As doutrinas existencialistas, Porto, Livraria Tavares Martins, 1953, p. 325.

20. E aqui reside o perigo de tendência ética reducionista, como aquela do movimento norte-americano Law and Biology, para o qual a moralidade nào tcm outra naturcza scnào a de constituir "empirical matter subject to scientific studly", aprescntando-se não com um substrato filosófico, mas tão-apcnas como "empirical issues of social science", asscmclhando a experiência juridica àqucla submctida às lcis biológicas. (Cf. E. Donald Elliot, Law and biology: the new synthesis?, Saint Louis University Law, v. 4l, n. 2, spring 1997, pp. 601-603)

21. La clonazione sull"uomo: una recente questione bioetica e biogiuridica, in Rivista internazionale di filosofia del diritto, Milano, Giuffrè, Luglio/Settembre, IV Seric, LXXIV - 1997, p. 462. 
dos movimentos individuais e sociais. Se é verdade não se identificar em todos os planos, numa projeção necessária, o direito com a ordem moral ${ }^{22}$, ou com os valores espirituais e religiosos, a situar-se o jurídico dentro do denominado "mínimo ético", cumprindo a finalidade de "manter de pé a sociedade dos homens e criar-lhes condições de vida que lhes permitam realizar; por si, os seus próprios fins '23 não menos correto estarem as normas jurídicas a positivar valores imantados a bens de essencial relevância ao convivio em sociedade, principal e primeiramente aqueles bens que dizem com a própria existência do homem e seu destino.

É nessa perspectiva que deve ser vista a questão relativa à Biotecnologia. Deve-se humanizá-la. Compatibilizá-la com os valores essenciais da humanidade, pondo-se a dignidade da pessoa humana como valor fonte, verdadeiro valor iluminador (Strahalwert), que informa, conforma e "enforma" todos os demais valores, inclusive e principalmente o juridico, e que dá projeção linear e significado inconfundível a toda descoberta científica e a toda a técnica utilizada pelo homem para esse fim.

Os organismos internacionais têm-se precatado dos riscos aos direitos individuais fundamentais consistentes nos grandes interesses econômicos no âmbito das investigações biotecnológicas. No encontro preparatório para o Global Compact Meeting realizado em 26 de julho de 2000, em Nova York, pela United Nations High Commissioner for Human Rights, o problema foi trazido de maneira pungente, apontando-se a preocupação quanto à crescente dependência e intercomunicação entre negócio e direitos humanos: "the links between business and human rights are becoming increasingly clear and higher on the international agenda"

A mesma United Nations expediu a Declaração Universal sobre o Genoma Humano e os Direitos Humanos, afirmando a unidade fundamental de todos os membros da família humana, com reconhecimento de sua inerente dignidade e diversidade. Por isso, todos têm o direito a respeito e à observação de sua dignidade e demais direitos independentemente de suas características genéticas, não se podendo reduzir o indivíduo à sua expressão ou qualidade genética, mas sim dedicar respeito à sua singularidade e diversidade.

Quanto à exploração aos interesses econômicos com as experiências genéticas, fixou que o genoma humano em seu estado natural não deve ser utilizado para ganhos financeiros, prevendo que, em caso de intervenção genética de que decorra danos ao paciente, mesmo em caso de consentimento, deverá haver reparação. Por isso, prevê-se que os Estados deverão editar regras expressas sobre os casos e condições de intervenção genética, mesmo consentida, limitando-se legalmente as hipóteses limitadoras.

E essas limitações jurídicas são de suma importância, em especial na área farmacêutica. Como assinalou o jornalismo do site Terra, "as transformações serão profundas, principalmente na área farmacêutica. Quando se detalharem as

22. Non omne quod licet honestum est.

23. Cabral de Moncada, op. cit., p. 295. 
tendências humanas a determinadas doenças, será aberto um novo leque de pesquisas em medicamentos, principalmente de caráter preventivo. Será possível prever a reação de cada homem a determinadas substâncias e economizar nos testes clinicos de diagnóstico. $O$ desenvolvimento de produtos transgênicos deverá ganhar ainda mais impulso, esquentando a polemica"

"Novos produtos - continua - poderão se beneficiar das descobertas. Empresas norte-americanas de biotecnologia estão conduzindo experiências de evolução acelerada para criar uma geração desde superdetergentes a remédios ultrapotentes. Na chamada evolução dirigida, os biotecnólogos pressionam os genes a experimentar mutações, obtendo em dias ou semanas o que demoraria anos na natureza. Por exemplo: determinadas bactérias levan décadas para evoluir e se tornar resistentes aos antibióticos. Os laboratórios, porém, podem criar em poucos dias supergermes para testar os novos antibióticos". ${ }^{24}$

Subjaz a todas essas considerações a indagação quanto à conveniência, necessidade ou mesmo emergência de se estabelecerem limites à investigação científica e à utilização de suas conquistas. O certo, contudo, é que o objetivo da pesquisa genética deverá ser o de preservação da vida e do bem-estar da pessoa humana, individualmente considerada, revestida de seus aspectos e atributos fundamentais de dignidade e diversidade.

A pesquisa genética, destarte, não poderá tanger a dignidade da pessoa humana, consistente em sua singularidade, diversidade, intimidade, ou seja, o valor intrínseco de sua personalidade. A terapia genética poderá ser incrementada para o aperfeiçoamento da espécie, nunca para o propósito genérico de criação ou geração de superespécies ou raças puras, mas deverá visar ao consentido aprimoramento da pessoa individualmente considerada.

Não deverão as pesquisas genéticas no campo humano, em particular no de fertilização, subverter a ordem natural da vida, em si mesma valiosa, por exemplo, com programa de concepção entre homossexuais.

De outro lado, as investigações genéticas não deverão caminhar para a perpetuação da espécie humana, porquanto tal vereda conduzirá, pela escassez dos recursos havidos no planeta, ao aniquilamento da própria Humanidade, a que precederia uma luta feroz entre os membros da raça humana.

VI. A vida humana como caminho para a morte: as fronteiras da genética.

A vida, em suma, há de prestar tributo à morte como limite derradeiro de uma existência que se faz outra mais perfeita, em outro plano, para que a linha da vida e da civilização humana não se interrompa.

A vida e a morte constituem extremos perenes de contato com a natureza mesma e com a própria Humanidade. A vida encaminha-se para a morte e nela se 
encontra paradoxalmente sua realização e sua plenitude, quando permite ao ser que morre a perpetuidade da própria existência na memória dos que sobram e na História da Humanidade, e o renascimento para a vida no plano espiritual, danação eterna para uns e gozo eterno para outros, tudo a depender das particulares escollias dos valores eternos.

A morte, por outro lado, dá sentido à vida e permite a continuidade da existência humana.

Há que se permitir ao homem morrer sua própria morte. Por isso, o que se lhe deve oferecer é qualidade de vida e também qualidade de morte, sem sofrimento ou dor, falando os psicólogos e médicos da "dignificação do processo de morrer" ${ }^{25}$

E qualidade de vida não se resume à funcionalidade e higidez de membros, órgãos, faculdades e funções, mas principalmerite resolve-se a qualidade de vida, no sabor da existência. Quando se perde o gosto da vida, pela solidão da ausência da constelação de familiares e queridos, pela desconexão progressiva do processo e progresso social, pelo desplugar-se do mundo, de nada vale a saúde física ou a higidez mental. É hora de morrer.

Por isso, deve-se respeitar a decisão personalíssima de quem se desapaixona da vida, por nela já não perceber atrativo ou com ela já não pulsar.

Tem razão, portanto, o Dr. Weir quando afirma que, por amar sua mulher, haver-lhe incondicionalmente e irreversivelmente prometido "não a trazer de volta"

Não será essa a razão pela qual o Salmista conclui, na perspectiva de seu tempo: " $A$ vida do homem é de setenta anos, mas se alguns por sua robustez chegam a oitenta o melhor deles é canseira e enfado"? ${ }^{26}$

A Biotecnologia, os estudos avançados de Genética e as pesquisas de ponta poderão com sucesso retirar do homem sua canseira, mas não serão capazes, jamais, de retirar-lhe o enfado, que é o cansaço da alma.

VII. Conclusão.

A ciência foi feita para o homem e não o homem construído a partir e na medida da ciência. Se, como Kant, a ciência é dotada de objetividade, necessidade e universalidade, mas em dependência da "subjetividade comum a todos os homens" 27 da consciência também universal e geral de todos os homens, o denominado " $E u$ transcendental", que organiza a multiplicidade das sensações segundo uma hierarquia de formas, de modo a constituir o conhecimento científico, o homem, como assinala o mesmo Kant, o homem é a medida moral da ciência e não pode ser de nenhum modo instrumentalizado. Ele é fim. Fim absoluto.

25. Kovacs, M. J., Autonomia e o direito de morrer com dignidade, $\mathrm{cm}$ Bioética, revista publicada pelo Conselho Federal de Medicina, v. 6, n. 1, 1998, p. 62.

26. Bíblia Sagrada, Livro dos Salmos, capitulo 90, versículo 10.

27. Umberto Padovani c Luis Castagnola, História da filosofia, São Paulo, Mclhoramcntos, 1993, p. 363. 
Será que vale a pena buscar a eternidade sem passar pela morte? Não traria a vida sem termo mais escolhos, mais patrimônio de sofrimento e dor do que bem-estar e sensação de completitude. Não constitui a morte o ápice de uma trajetória de vida que pretende a eternidade para imortalidade da própria existência.

Como diz Moisés no Livro dos Salmos, falando da fraqueza do homem e da providência de Deus: "A duração da nossa vida é de setenta anos, e se alguns, pela sua robustez chegam a oitenta anos, o melhor deles é canseira e enfado, pois passa rapidamente, e nós voamos" 28

Do homem, repita-se, não se lhe pode extrair o direito de morrer. O direito de morrer sua própria morte, com todo o ritmo e o completo rito sacro e de sagração reservados a cada ser humano. Há beleza na morte. A cessação da vida a um só tempo é cessação de trajetória e reinício de jornada, é a consolidação de um projeto e realização de vida, para a instauração de um outro projeto de realização de vida, no plano transcendental. ${ }^{29}$ Nesse sentido, o nascimento do mito nada mais significa senão o cristalizar, perenizando na personalidade que morreu, suas virtudes e seu exemplo. Somente se pode tornar eterno passando pela via sombria e gloriosa da morte. A imortalidade de um Kennedy, Churchill, a lembrança perene de um Getúlio Vargas ou Rui Barbosa, o exemplo contínuo e renovado de um Gandhi ou Ayrton Senna, ou de um Charles Chaplin, apenas foram obtidos pela morte.

A morte, numa palavra, traz vantagens e ganhos a quem morre, que pode passar a viver num estado de perfeição, e aos que persistem na senda da vida, que têm um referencial para a existência, um norte para seu destino.

Por isso o filósofo e cientista, ou melhor, esteta do Direito, Miguel Reale, pontua não ser exagero "afirmar que sem a morte não teria significado a vida. Imaginese o homem imortal, para quem a infância, juventude, maturidade e velhice seriam palavras desprovidas de sentido, um tempo sempre igual, no qual não haveria lugar nem para esperança, nem para a saudade" 30

Se como diz Voltaire a "vida é organização com capacidade de sentir" as pesquisas genéticas inspiradas apenas tecnicamente não poderão ingressar no patrimônio humano, senão quando ganharem vida, pela presença do sentimento do homem, pela via aberta da humanização.

São Paulo, fevereiro de 2002.

28. Bíblia Sagrada, Salmo 90: J0, versão Almcida.

29. Assim, parcce não ter razão Rui Barbosa quando dizia: "A vida não tem mais que duas portas: uma de entrar pelo nascimento; outra de sair; pela morte. Ninguém, cabendo-lhe a vez, poderá furtar à entrada. Ninguèn, desde que entrou em lhe chegando o turno, se conseguirá evadir à saidla". (Elogios acadêmicos e orações de paraninfo, Ed, Revista de Língua Portugucsa, 1924, p. 358.

30. Artigo publicado no jornal "O Estado de S. Paulo"-12/6/99.

31. Diccionário fisolófico, Bucnos Aircs, Editorial Araújo, 1964, Tomo III, verbetc “vida”, p. 354. 